\title{
Determination of Mobile Addiction and Social Media Addiction Level of Parents and Their Attitudes Towards Usage of Technology
}

\author{
https://doi.org/10.3991/ijet.v14i22.11770 \\ Sezer Kanbul ( $₫$ ) \\ Near East University, Nicosia, Turkey \\ sezer.kanbul@ neu.edu.tr \\ Taymuraz E. Kallagov \\ Gorsky State Agrarian University, Vladikavkaz, Russia \\ Vladimir E. Rubanik \\ Financial University under the Government of the Russian Federation, \\ Moscow, Russia \\ Elmira R. Khairullina \\ Kazan National Research Technological University, Kazan, Russia \\ Laysan A. Ribakova \\ Kazan (Volga region) Federal University, Kazan, Russia
}

\begin{abstract}
The objective of this study is to determine the mobile addiction and social media addiction level of parents and their attitudes towards usage of technology. The study has a descriptive and correlational model pattern which is a quantitative research method. The sample of the study consisted of 200 preschool student parents. In order to collect the data, "Mobile Addiction Scale", "Social Media Addiction Scale" and "Parent Attitude towards Technology Usage Scale" were used and the descriptive statistics of the scale scores and the relational findings between the scale scores were included. Accordingly, statistically significant and positive correlations were found between the scores of parents' subscales in the 'Parental Attitude Scale for Technology Usage and 'Mobile Addiction Scale'. It is hoped that the study will shed light on other researchers in terms of their attitudes towards mobile and social media addiction levels and usage of technology.
\end{abstract}

Keywords - Mobile addiction, social media addiction, usage of technology, attitude, parent. 


\section{Introduction}

According to the "Household Informatics Technologies Usage Study" conducted by Turkish Statistics Institute-TUIK, computer and internet usage in Turkey was found as $59.6 \%$ and $72.9 \%$ in $16-74$ age group family members, respectively [1].

As a result of the widespread use of the internet with technological developments, mobile phones have become the most widely used technological devices in the social structure. With the mobile devices produced in the last decade, almost all operations can be performed which could be conducted with a computer. Especially with smart phones that provide access to the internet, the time spent with mobile phones increases for people who obtain many advantages. Such excessive use of mobile phones is becoming an addiction in society. The ability to access the internet with mobile phones at any time, the social media applications, and online mobile games they offer increase internet and mobile addiction $[2,3,17,19,20]$.

With the emergence of web 2.0 technologies operated on the internet, individuals became users of social networks and became content-producers through the account they created. As the case for each of the technological addictions, it is inevitable for individuals of all ages to spend excessive time on social media and consequently have problems in fulfilling their personal, social, educational and professional responsibilities, as well as experience various psychological, physical and social problems $[4,5,18]$.

With the rapid progress of technology, technological tools that meet the educational needs in the educational dimension have become indispensable elements of the educational components. These tools and materials have become increasingly widespread in recent years, and began to be used continuously in educational and training environment. In order to elevate the education to the desired level, parents of students should develop positive attitudes towards classes and technology as the most important educational institution of the child is the family environment. The family is where informal education of the child begins. Children's positive attitudes towards classes and technology and their beneficial use of technology depend largely on the positive attitudes and behaviors of their parents. If parents create the necessary awareness to show positive behaviors, it is possible for children to benefit from technology properly $[6,7]$. First of all, parents should use their mobile phones and social media tools only to the extent that they need, and they should not be addictive.

In this context, the aim of the study is to determine the attitudes of students' parents towards mobile addiction and social media addiction levels and technology usage. For this purpose, the following sub-objectives have been identified.

1. What is the distribution of parents' socio-demographic characteristics?

2. What is the distribution of parents' use of technology?

3. What are the parents' scores on the parental attitude scale, mobile addiction scale and social media addiction scale?

4. Is there a significant difference between the scores obtained by parents in parental attitude scale for technology usage, mobile addiction scale and social media addiction scale in terms of: 
- Gender

- Age group

- Daily internet usage time

- Type of mobile operation system

5. Is there a significant correlation between the scores obtained from parental attitude scale for technology usage, mobile addiction scale and social media addiction scale.

\section{$2 \quad$ Methods}

\section{$2.1 \quad$ Research model}

This study was designed by Descriptive and Correlational research model, which is a quantitative research approach, to define the current situation [8]. In the correlation model, the relationship between variables and the level of this relationship is determined [9].

\subsection{Sample of the study}

The universe of this research consists of 2100 students in a faculty of education affiliated to a private university in 2018-2019 academic year. The sample consisted of 200 students who were determined by $95 \%$ confidence level based on simple random sampling method.

In the simple random sampling method, the selection of each unit in the universe is made impartially considering the possibility of being equal equality and independence in the selection of sampling [10].

\subsection{Collection of data}

Three different scale forms and a demographic information form prepared by the authors were used to determine the attitudes of students' parents towards mobile addiction and social media addiction levels and technology usage in data collection.

The scales used were 'Development and Validation of the Mobile Addiction Scale' developed by Fidan, 'Social Media Addiction Scale - Adult Form' developed by Sahin and Yagci and 'Parents' Attitude Scale Regarding Technology developed by Kenar $[3,4,11]$.

\subsection{Analysis of data}

IBM SPSS 24.0 software was used for statistical analysis of data set in the study. The frequency analysis of the socio-demographic characteristics, technology and internet usage of the parents was performed. In addition, descriptive statistics related 
to the scores obtained from Parental Attitude Scale for Technology Use, Mobile Addiction Scale and Social Media Addiction Scale were shown.

Parental Attitude for Technology Usage Scale, Mobile Addiction Scale and Social Media Addiction Scale scores of parents were examined by Kolmogorov-Smirnov and Shapiro-Wilk tests. Mann-Whitney U test was used for comparisons where the independent variable had two categories, and Kruskal-Wallis H test was used for comparisons had more than two categories. The correlations between Parental Attitude Scale for Technology Use, Mobile Addiction Scale and Social Media Addiction Scale were tested with Spearman test.

\section{$3 \quad$ Findings}

Table 1. Distribution of socio-demographic features of parents $(n=200)$

\begin{tabular}{|l|c|c|}
\hline \multicolumn{1}{|c|}{ f } & \% \\
\hline Gender & & 55,00 \\
\hline Female & 110 & 45,00 \\
\hline Male & 90 & \\
\hline Age group & & 27,00 \\
\hline Less than 34 year & 54 & 40,00 \\
\hline $35-39$ years & 80 & 33,00 \\
\hline 40 years and older & 66 & \\
\hline Education & & 16,50 \\
\hline Primary education & 33 & 32,50 \\
\hline High school & 65 & \\
\hline Undergraduate / Graduate & 102 & 88,00 \\
\hline Internet connection at home & & 12,00 \\
\hline Yes & 176 & \\
\hline No & 24 & 34,00 \\
\hline Internet connection at home & & 21,00 \\
\hline Less than 3 hour & 88 & 35,00 \\
\hline $3-5$ hours & 42 & \\
\hline More than 5 hours & 70 & \\
\hline Mobile phone OS & & \\
\hline IOS & & \\
\hline Android & & \\
\hline
\end{tabular}

An examination of the results of frequency analysis given in Table 2 shows that $55.0 \%$ of the participants are females and $45.0 \%$ are males, $27.0 \%$ are 34 years of age and younger, $40.0 \%$ are $35-39$ years of age, and $33.0 \%$ are 40 years of age and older, $32.50 \%$ are high school graduates and $51.0 \%$ are undergraduate/graduate degree holders. It is seen that among the parents who participated in the study, $44.0 \%$ used internet for less than 3 hours a day, 21.0\% used internet for 3-5 hours a day, 35.0\% used internet for 5 hours and more a day, 33.0\% used IOS mobile operating system and $67.0 \%$ used android operating system. 
Table 2. Distribution of technology usage of parents $(n=200)$

\begin{tabular}{|l|c|c|}
\hline & f & \% \\
\hline Purpose of mobile phone use * & & 79,00 \\
\hline for interview purposes & 158 & 56,50 \\
\hline Follow the news & 113 & 18,50 \\
\hline Game & 37 & 42,50 \\
\hline Education & 85 & 69,50 \\
\hline Social networks & 139 & 5,50 \\
\hline other & 11 & 67,50 \\
\hline Owned social media accounts * & & 60,50 \\
\hline Facebook & 135 & 78,00 \\
\hline Youtube & 121 & 21,50 \\
\hline WhatsApp & 156 & 14,00 \\
\hline Viber & 43 & 66,00 \\
\hline Snapchat & 28 & 16,50 \\
\hline Instagram & 132 & 3,50 \\
\hline Twitter & 33 & 5,50 \\
\hline Linkedin & 7 & 78,50 \\
\hline other & 11 & 8,50 \\
\hline Intended use of social media * & 138 \\
\hline to follow new news & 152 & \\
\hline to communicate with friends & & \\
\hline to spend time & & \\
\hline other & & \\
\hline
\end{tabular}

*Multiple answers can be given.

When the findings regarding the distribution of technology use characteristics of the parents given in Table 2 are examined, it is seen that $79.0 \%$ of the parents used mobile phone for making calls, $69.50 \%$ for social networks, $56.50 \%$ for following news and $42.50 \%$ for educational purposes.

It was seen that $78,0 \%$ of the parents had Whatsapp, $67,50 \%$ had Facebook, $66,0 \%$ had Instagram and $60.50 \%$ had Youtube accounts. $76.0 \%$ of the parents who participated in the study stated that they used social media to communicate with their friends, $69.0 \%$ to follow flash news and $48.50 \%$ to spend time. 
Table 3. Parental attitude scale for technology use, mobile addiction scale and social media addiction scale scores $(\mathrm{n}=200)$

\begin{tabular}{|l|c|c|c|c|c|}
\hline & $\mathbf{n}$ & $\overline{\boldsymbol{x}}$ & $\mathbf{s}$ & Min & Max \\
\hline Socio-Psychological Development & 200 & 25,26 & 7,39 & 11 & 52 \\
\hline Interest and Success & 200 & 24,06 & 5,91 & 7 & 35 \\
\hline Internal and External Quality of the Course & 200 & 14,11 & 3,86 & 4 & 20 \\
\hline Learning and Participation & 200 & 10,22 & 2,51 & 3 & 15 \\
\hline Evidence & 200 & 10,25 & 3,62 & 4 & 20 \\
\hline Tolerance & 200 & 11,29 & 4,13 & 4 & 20 \\
\hline Estrangement & 200 & 10,24 & 3,98 & 4 & 20 \\
\hline Emotional Change & 200 & 10,76 & 3,50 & 4 & 20 \\
\hline Conflict & 200 & 10,51 & 3,68 & 4 & 20 \\
\hline Repeat & 200 & 10,55 & 4,03 & 4 & 20 \\
\hline Mobile Internet Trend & 200 & 12,78 & 3,52 & 4 & 20 \\
\hline Mobile Addiction & 200 & 14,38 & 4,37 & 5 & 25 \\
\hline Virtual Tolerance & 200 & 29,61 & 8,69 & 11 & 55 \\
\hline Virtual Communication & 200 & 23,79 & 7,97 & 9 & 45 \\
\hline
\end{tabular}

In Table 3, descriptive statistics related to the scores obtained by parents in the study from Parental Attitude Scale for Technology Use, Mobile Addiction Scale and Social Media Addiction Scale are given.

It is observed that, as regards the Parental Attitude Scale for Technology Use, parents who participated in the study obtained $\mathrm{x}^{-}=25,26 \pm 7,39$ points from Sociopsychological development sub-dimension, $x=24,06 \pm 5,91$ points from interest and success in the course sub-dimension, $x=14,11 \pm 3,86$ points from internal and external qualification of the course sub-dimension, and $\mathrm{x}^{-}=10,22 \pm 2,51$ points from Learning and participating in the course sub-dimension.

As regards Parents Mobile Addiction Scale, the parents received $\mathrm{x}^{-}=10,25 \pm 3,62$ points from markedness sub-dimension, $x=11,29 \pm 4,13$ from Tolerance sub-scale, $x^{-}=10,24 \pm 3,98$ from emotional change sub-dimension, $x^{-}=10,51 \pm 3,68$ points from conflict sub-dimension, $\mathrm{x}^{-}=10,55 \pm 4,03$ points from repetition sub-dimension, $\mathrm{x}=12,78 \pm 3,52$ points from Mobile internet education sub-dimension, and $\mathrm{x}=14,38 \pm 4,37$ points from Mobile addiction sub-dimension.

It has been found out that as regards Social Media Addiction Scale, the parents who participated in the study received $x^{-}=29,61 \pm 8,69$ points from virtual tolerance sub-dimension and $\mathrm{x}^{-}=23,79 \pm 7,97$ points from virtual communication sub-dimension. 
Table 4. Parental attitude scale for technology use, mobile addiction scale and social media addiction scale scores according to the gender of parents $(n=200)$

\begin{tabular}{|c|c|c|c|c|c|c|c|c|}
\hline & Gender & $\mathbf{n}$ & $\overline{\boldsymbol{x}}$ & $\mathbf{s}$ & M & SO & $\mathbf{Z}$ & $\mathbf{p}$ \\
\hline \multirow{2}{*}{$\begin{array}{l}\text { Socio-Psychological } \\
\text { Development }\end{array}$} & Female & 110 & 25,15 & 7,56 & 24,00 & 97,90 & \multirow{2}{*}{$-0,704$} & \multirow{2}{*}{0,481} \\
\hline & Male & 90 & 25,38 & 7,22 & 25,00 & 103,68 & & \\
\hline \multirow{2}{*}{ Interest and Success } & Female & 110 & 24,57 & 5,94 & 26,00 & 106,56 & \multirow{2}{*}{$-1,643$} & \multirow{2}{*}{0,100} \\
\hline & Male & 90 & 23,43 & 5,85 & 24,00 & 93,09 & & \\
\hline \multirow{2}{*}{$\begin{array}{l}\text { Internal and External } \\
\text { Quality of the Course }\end{array}$} & Female & 110 & 14,37 & 3,47 & 15,00 & 103,40 & \multirow{2}{*}{$-0,787$} & \multirow{2}{*}{0,431} \\
\hline & Male & 90 & 13,79 & 4,28 & 14,50 & 96,96 & & \\
\hline \multirow{2}{*}{$\begin{array}{l}\text { Learning and Participa- } \\
\text { tion }\end{array}$} & Female & 110 & 10,30 & 2,39 & 11,00 & 102,23 & \multirow{2}{*}{$-0,473$} & \multirow{2}{*}{0,636} \\
\hline & Male & 90 & 10,12 & 2,66 & 10,00 & 98,38 & & \\
\hline \multirow{2}{*}{ Evidence } & Female & 110 & 9,83 & 3,42 & 10,00 & 94,70 & \multirow{2}{*}{$-1,578$} & \multirow{2}{*}{0,115} \\
\hline & Male & 90 & 10,76 & 3,81 & 10,00 & 107,59 & & \\
\hline \multirow{2}{*}{ Tolerance } & Female & 110 & 10,95 & 4,30 & 10,00 & 94,89 & \multirow{2}{*}{$-1,522$} & \multirow{2}{*}{0,128} \\
\hline & Male & 90 & 11,71 & 3,89 & 11,50 & 107,36 & & \\
\hline \multirow{2}{*}{ Estrangement } & Female & 110 & 9,75 & 4,13 & 8,00 & 92,97 & \multirow{2}{*}{$-2,048$} & \multirow{2}{*}{$0,041^{*}$} \\
\hline & Male & 90 & 10,84 & 3,73 & 11,00 & 109,70 & & \\
\hline \multirow{2}{*}{ Emotional Change } & Female & 110 & 10,29 & 3,47 & 10,00 & 92,01 & \multirow{2}{*}{$-2,303$} & \multirow{2}{*}{$0,021^{*}$} \\
\hline & Male & 90 & 11,32 & 3,46 & 11,00 & 110,87 & & \\
\hline \multirow{2}{*}{ Conflict } & Female & 110 & 10,19 & 3,81 & 9,00 & 95,19 & \multirow{2}{*}{$-1,442$} & \multirow{2}{*}{0,149} \\
\hline & Male & 90 & 10,89 & 3,50 & 10,00 & 106,99 & & \\
\hline \multirow{2}{*}{ Repeat } & Female & 110 & 10,02 & 3,87 & 9,00 & 92,87 & \multirow{2}{*}{$-2,072$} & \multirow{2}{*}{$0,038^{*}$} \\
\hline & Male & 90 & 11,20 & 4,14 & 11,00 & 109,83 & & \\
\hline Mohile Internet Trend & Female & 110 & 12,84 & 3,57 & 13,00 & 101,94 & & \\
\hline Mobile Internet Trend & Male & 90 & 12,71 & 3,48 & 12,00 & 98,74 & 390 & 0,697 \\
\hline & Female & 110 & 14,28 & 4,25 & 14,00 & 99,53 & & \\
\hline Mobile Addiction & Male & 90 & 14,49 & 4,54 & 14,00 & 101,68 & $-0,262$ & 0,793 \\
\hline & Female & 110 & 29,00 & 8,54 & 28,00 & 96,04 & & \\
\hline Virtual Tolerance & Male & 90 & 30,34 & 8,86 & 29,00 & 105,95 & $-1,206$ & 0,228 \\
\hline & Female & 110 & 23,20 & 7,77 & 23,00 & 97,27 & & \\
\hline Virtual Commun & Male & 90 & 24,51 & 8,19 & 23,00 & 104,44 & $-0,873$ & 0,383 \\
\hline
\end{tabular}

$* \mathrm{p}<0,05$

Table 4. shows the results of the Mann-Whitney $U$ test for the comparison of the scores obtained by the Parental Attitude Scale for Technology Use, Mobile Addiction Scale and Social Media Addiction Scale according to the gender of the parents.

It was found that there was no statistically significant difference between sociopsychological development, interest and success, internal and external quality of the course, learning and participation subscale scores in the Parental Attitude Scale for Technology Use according to the gender of the participating parents $(p>0,05)$.

It was found that the difference between the scores obtained from the subscales of significance, tolerance, conflict, mobile internet tendency and mobile addiction in the Mobile Dependency Scale according to the gender of the parents was not statistically significant $(\mathrm{p}>0.05)$. It was also found that the difference between the scores obtained from the sub-dimensions of divergence, emotional change and repetition of the Mobile Dependency Scale was statistically significant according to the gender of the 
parents $(\mathrm{p}<0.05)$. Male parents' scores of divergence, emotional change and repetition subscales were higher than females.

There was no statistically significant difference between the scores obtained from the virtual tolerance and virtual communication sub-dimensions of the Social Media Addiction Scale of the male and female parents included in the study ( $p>0.05)$.

Table 5. Parental attitude scale for technology use, mobile addiction scale and social media addiction scale scores according to the age of parents $(n=200)$

\begin{tabular}{|c|c|c|c|c|c|c|c|c|c|}
\hline & Age group & n & $\overline{\bar{x}}$ & $\mathbf{s}$ & M & SO & $\mathbf{Z}$ & $\mathbf{p}$ & d \\
\hline \multirow{3}{*}{$\begin{array}{l}\text { Socio-Psychological } \\
\text { Development }\end{array}$} & Less than 34 year & 54 & 24,20 & 7,43 & 23,00 & 93,33 & 5,427 & 0,066 & \\
\hline & $35-39$ years & 80 & 26,71 & 6,72 & 26,50 & 112,15 & & & \\
\hline & $\begin{array}{l}40 \text { years and } \\
\text { older }\end{array}$ & 66 & 24,35 & 7,93 & 24,00 & 92,24 & & & \\
\hline \multirow{3}{*}{ Interest and Success } & Less than 34 year & 54 & 24,50 & 5,62 & 26,00 & 104,83 & $\begin{array}{c}10,35 \\
7\end{array}$ & $\begin{array}{c}0,006 \\
*\end{array}$ & $1-3$ \\
\hline & $35-39$ years & 80 & 25,46 & 5,16 & 26,00 & 112,58 & & & $2-3$ \\
\hline & $\begin{array}{l}40 \text { years and } \\
\text { older }\end{array}$ & 66 & 22,00 & 6,48 & 22,00 & 82,32 & & & \\
\hline \multirow{3}{*}{$\begin{array}{l}\text { Internal and External } \\
\text { Quality of the Course }\end{array}$} & Less than 34 year & 54 & 14,54 & 3,71 & 15,00 & 105,84 & $\begin{array}{c}10,89 \\
9\end{array}$ & $\begin{array}{c}0,004 \\
*\end{array}$ & $1-3$ \\
\hline & 35-39 years & 80 & 14,95 & 3,45 & 15,50 & 112,38 & & & $2-3$ \\
\hline & $\begin{array}{l}40 \text { years and } \\
\text { older }\end{array}$ & 66 & 12,74 & 4,11 & 13,00 & 81,73 & & & \\
\hline \multirow{3}{*}{$\begin{array}{l}\text { Learning and Partici- } \\
\text { pation }\end{array}$} & Less than 34 year & 54 & 10,44 & 2,20 & 10,00 & 103,99 & 7,230 & $\begin{array}{c}0,027 \\
*\end{array}$ & $1-3$ \\
\hline & $35-39$ years & 80 & 10,69 & 2,29 & 11,00 & 110,56 & & & $2-3$ \\
\hline & $\begin{array}{l}40 \text { years and } \\
\text { older }\end{array}$ & 66 & 9,47 & 2,84 & 10,00 & 85,45 & & & \\
\hline \multirow{3}{*}{ Evidence } & Less than 34 year & 54 & 9,44 & 3,81 & 9,50 & 87,56 & 3,768 & 0,152 & \\
\hline & 35-39 years & 80 & 10,61 & 3,63 & 10,00 & 105,89 & & & \\
\hline & $\begin{array}{l}40 \text { years and } \\
\text { older }\end{array}$ & 66 & 10,45 & 3,40 & 10,00 & 104,55 & & & \\
\hline \multirow{3}{*}{ Tolerance } & Less than 34 year & 54 & 10,22 & 4,34 & 10,00 & 85,57 & 7,215 & $\begin{array}{c}0,027 \\
*\end{array}$ & $1-2$ \\
\hline & 35-39 years & 80 & 12,13 & 4,25 & 12,50 & 112,51 & & & \\
\hline & $\begin{array}{l}40 \text { years and } \\
\text { older }\end{array}$ & 66 & 11,15 & 3,61 & 11,00 & 98,15 & & & \\
\hline \multirow{3}{*}{ Estrangement } & Less than 34 year & 54 & 9,43 & 4,45 & 8,00 & 85,66 & 5,820 & 0,054 & \\
\hline & $35-39$ years & 80 & 10,28 & 3,87 & 10,00 & 101,93 & & & \\
\hline & $\begin{array}{l}40 \text { years and } \\
\text { older }\end{array}$ & 66 & 10,86 & 3,62 & 11,00 & 110,91 & & & \\
\hline \multirow{3}{*}{ Emotional Change } & Less than 34 year & 54 & 9,74 & 3,67 & 10,00 & 82,31 & 7,452 & $\begin{array}{c}0,024 \\
*\end{array}$ & $1-2$ \\
\hline & $35-39$ years & 80 & 11,06 & 3,62 & 11,00 & 106,05 & & & $1-3$ \\
\hline & $\begin{array}{l}40 \text { years and } \\
\text { older }\end{array}$ & 66 & 11,21 & 3,05 & 11,00 & 108,66 & & & \\
\hline \multirow{2}{*}{ Conflict } & Less than 34 year & 54 & 9,63 & 3,96 & 8,00 & 84,01 & 7,893 & $\begin{array}{c}0,019 \\
*\end{array}$ & $1-2$ \\
\hline & $35-39$ years & 80 & 11,11 & 3,54 & 12,00 & 112,44 & & & \\
\hline
\end{tabular}




\begin{tabular}{|c|c|c|c|c|c|c|c|c|}
\hline & $\begin{array}{l}40 \text { years and } \\
\text { older }\end{array}$ & 66 & 10,48 & 3,51 & 10,00 & 99,52 & & \\
\hline \multirow{3}{*}{ Repeat } & Less than 34 year & 54 & 9,63 & 4,41 & 9,00 & 85,42 & 5,595 & 0,061 \\
\hline & 35-39 years & 80 & 11,09 & 4,09 & 12,00 & 109,20 & & \\
\hline & $\begin{array}{l}40 \text { years and } \\
\text { older }\end{array}$ & 66 & 10,65 & 3,52 & 11,00 & 102,30 & & \\
\hline \multirow{3}{*}{ Mobile Internet Trend } & Less than 34 year & 54 & 12,94 & 3,81 & 13,00 & 103,50 & 1,611 & 0,447 \\
\hline & 35-39 years & 80 & 13,10 & 3,63 & 13,00 & 104,53 & & \\
\hline & $\begin{array}{l}40 \text { years and } \\
\text { older }\end{array}$ & 66 & 12,26 & 3,11 & 12,00 & 93,16 & & \\
\hline \multirow{3}{*}{ Mobile Addiction } & Less than 34 year & 54 & 14,44 & 4,97 & 14,00 & 99,53 & 0,031 & 0,985 \\
\hline & 35-39 years & 80 & 14,31 & 3,86 & 14,00 & 100,43 & & \\
\hline & $\begin{array}{l}40 \text { years and } \\
\text { older }\end{array}$ & 66 & 14,39 & 4,50 & 14,00 & 101,39 & & \\
\hline \multirow{3}{*}{ Virtual Tolerance } & Less than 34 year & 54 & 28,67 & 10,36 & 27,00 & 90,69 & 2,636 & 0,268 \\
\hline & 35-39 years & 80 & 29,23 & 7,45 & 29,00 & 101,04 & & \\
\hline & $\begin{array}{l}40 \text { years and } \\
\text { older }\end{array}$ & 66 & 30,83 & 8,60 & 29,00 & 107,87 & & \\
\hline \multirow{3}{*}{$\begin{array}{l}\text { Virtual Communica- } \\
\text { tion }\end{array}$} & Less than 34 year & 54 & 22,80 & 8,32 & 22,00 & 93,19 & 1,335 & 0,513 \\
\hline & 35-39 years & 80 & 23,53 & 6,97 & 24,00 & 101,52 & & \\
\hline & $\begin{array}{l}40 \text { years and } \\
\text { older }\end{array}$ & 66 & 24,92 & 8,76 & 22,00 & 105,25 & & \\
\hline
\end{tabular}

$* \mathrm{p}<0,05$

Table 5 shows the results of the Kruskal-Wallis $\mathrm{H}$ test for the comparison of the scores obtained from the Parental Attitude Scale for Technology Use, Mobile Addiction Scale and Social Media Addiction Scale according to the age group of the parents included in the study.

It was found that there was no statistically significant difference between the scores of the parents who participated in the study from the sociopsychological development subscale of the Parental Attitude Scale for Technology Use according to age groups $(p>0.05)$. On the other hand, it was found that the difference between the points of interest and success, internal and external quality, learning and attendance subscales were statistically significant $(\mathrm{p}<0.05)$. The scores obtained by the parents aged 40 and over from the sub-dimensions of interest and success, internal and external quality of the course, learning and participation in the course were found to be lower than the parents in other age groups.

It was found that there was no statistically significant difference between the scores obtained from the markedness, divergence, repetition, mobile internet tendency and mobile addiction subscales of the Mobile Dependency Scale according to the age group ( $p>0.05$ ). There was a statistically significant difference between the scores obtained from the subscales of tolerance, emotional change and conflict in the Mobile Dependency Scale according to the age group of the parents $(p<0.05)$. Parents aged 34 years and younger received lower scores on tolerance, emotional change, and conflict sub-dimensions than those aged 35-39. In addition, parents aged 34 and under scored lower on the emotional change subdimension than individuals aged 40 and over. 
Table 6. Parental attitude scale for technology use, mobile addiction scale and social media addiction scale scores according to the daily internet usage time of parents $(n=200)$

\begin{tabular}{|c|c|c|c|c|c|c|c|c|c|}
\hline & Time & $\mathbf{n}$ & $\bar{x}$ & $\mathbf{s}$ & M & SO & $\mathbf{X}^{2}$ & $\mathbf{p}$ & d \\
\hline \multirow{3}{*}{$\begin{array}{l}\text { Socio- } \\
\text { Psychological } \\
\text { Development }\end{array}$} & Less than 3 hour & 88 & 25,07 & 7,45 & 24,50 & 99,64 & 0,201 & 0,905 & \\
\hline & 3-5 hours & 42 & 24,98 & 5,61 & 24,00 & 98,31 & & & \\
\hline & More than 5 hours & 70 & 25,66 & 8,28 & 25,00 & 102,90 & & & \\
\hline \multirow{3}{*}{$\begin{array}{l}\text { Interest and } \\
\text { Success }\end{array}$} & Less than 3 hour & 88 & 24,44 & 5,75 & 26,00 & 104,31 & 1,528 & 0,466 & \\
\hline & 3-5 hours & 42 & 24,62 & 5,22 & 25,50 & 103,98 & & & \\
\hline & More than 5 hours & 70 & 23,24 & 6,48 & 24,00 & 93,63 & & & \\
\hline \multirow{3}{*}{$\begin{array}{l}\text { Internal and } \\
\text { External Quality } \\
\text { of the Course }\end{array}$} & Less than 3 hour & 88 & 14,27 & 3,81 & 15,00 & 102,30 & 1,358 & 0,507 & \\
\hline & 3-5 hours & 42 & 14,60 & 3,18 & 15,00 & 106,79 & & & \\
\hline & More than 5 hours & 70 & 13,61 & 4,26 & 14,00 & 94,46 & & & \\
\hline \multirow{3}{*}{$\begin{array}{l}\text { Learning and } \\
\text { Participation }\end{array}$} & Less than 3 hour & 88 & 10,23 & 2,47 & 11,00 & 101,76 & 4,077 & 0,130 & \\
\hline & 3-5 hours & 42 & 10,81 & 2,18 & 11,00 & 113,49 & & & \\
\hline & More than 5 hours & 70 & 9,86 & 2,70 & 9,50 & 91,13 & & & \\
\hline \multirow{3}{*}{ Evidence } & Less than 3 hour & 88 & 9,66 & 3,35 & 10,00 & 92,75 & 6,339 & $0,042 *$ & $1-3$ \\
\hline & 3-5 hours & 42 & 9,86 & 3,54 & 10,00 & 93,51 & & & \\
\hline & More than 5 hours & 70 & 11,21 & 3,85 & 10,50 & 114,44 & & & \\
\hline \multirow{3}{*}{ Tolerance } & Less than 3 hour & 88 & 10,48 & 3,83 & 10,00 & 89,89 & 12,532 & $0,002 *$ & $1-3$ \\
\hline & 3-5 hours & 42 & 10,60 & 3,88 & 10,00 & 89,98 & & & $2-3$ \\
\hline & More than 5 hours & 70 & 12,73 & 4,31 & 13,00 & 120,15 & & & \\
\hline \multirow{3}{*}{ Estrangement } & Less than 3 hour & 88 & 9,49 & 3,69 & 8,00 & 90,63 & 7,803 & $0,020^{*}$ & $1-3$ \\
\hline & 3-5 hours & 42 & 9,83 & 3,80 & 10,00 & 95,80 & & & $2-3$ \\
\hline & More than 5 hours & 70 & 11,43 & 4,20 & 11,50 & 115,74 & & & \\
\hline \multirow{3}{*}{$\begin{array}{l}\text { Emotional Chan- } \\
\text { ge }\end{array}$} & Less than 3 hour & 88 & 10,42 & 3,56 & 10,00 & 95,06 & 3,918 & 0,141 & \\
\hline & 3-5 hours & 42 & 10,26 & 3,19 & 10,50 & 93,62 & & & \\
\hline & More than 5 hours & 70 & 11,47 & 3,53 & 11,00 & 111,46 & & & \\
\hline \multirow{3}{*}{ Conflict } & Less than 3 hour & 88 & 10,22 & 3,71 & 10,00 & 95,76 & 1,581 & 0,454 & \\
\hline & 3-5 hours & 42 & 10,26 & 3,42 & 10,00 & 99,18 & & & \\
\hline & More than 5 hours & 70 & 11,01 & 3,80 & 10,00 & 107,25 & & & \\
\hline \multirow{3}{*}{ Repeat } & Less than 3 hour & 88 & 10,13 & 3,91 & 10,00 & 95,51 & 2,540 & 0,281 & \\
\hline & 3-5 hours & 42 & 10,33 & 4,19 & 10,00 & 96,24 & & & \\
\hline & More than 5 hours & 70 & 11,21 & 4,05 & 11,00 & 109,34 & & & \\
\hline \multirow{3}{*}{$\begin{array}{l}\text { Mobile Internet } \\
\text { Trend }\end{array}$} & Less than 3 hour & 88 & 12,35 & 3,13 & 12,00 & 93,90 & 2,819 & 0,244 & \\
\hline & 3-5 hours & 42 & 13,36 & 3,67 & 14,00 & 111,79 & & & \\
\hline & More than 5 hours & 70 & 12,97 & 3,87 & 13,00 & 102,03 & & & \\
\hline
\end{tabular}




\begin{tabular}{|l|l|l|l|l|l|l|l|l|l|}
\hline \multirow{4}{*}{$\begin{array}{l}\text { Mobile Addic- } \\
\text { tion }\end{array}$} & Less than 3 hour & 88 & 13,93 & 3,64 & 14,00 & 95,98 & 2,302 & 0,316 & \\
\cline { 2 - 10 } & $3-5$ hours & 42 & 13,81 & 4,20 & 14,00 & 95,92 & & & \\
\cline { 2 - 10 } & More than 5 hours & 70 & 15,27 & 5,16 & 15,00 & 108,94 & & & \\
\hline \multirow{4}{*}{ Virtual Tolerance } & Less than 3 hour & 88 & 28,19 & 7,48 & 28,50 & 93,05 & 5,076 & 0,079 & \\
\cline { 2 - 10 } & $3-5$ hours & 42 & 28,43 & 7,95 & 28,50 & 95,27 & & & \\
\cline { 2 - 10 } & More than 5 hours & 70 & 32,09 & 10,01 & 31,00 & 113,00 & & & \\
\hline \multirow{3}{*}{$\begin{array}{l}\text { Virtual Commu } \\
\text { nication }\end{array}$} & Less than 3 hour & 88 & 22,64 & 7,20 & 21,50 & 93,10 & 5,180 & 0,075 & \\
\cline { 2 - 10 } & 3-5 hours & 42 & 22,62 & 6,55 & 22,50 & 94,94 & & & \\
\cline { 2 - 10 } & More than 5 hours & 70 & 25,94 & 9,22 & 25,00 & 113,14 & & & \\
\hline
\end{tabular}

$* \mathrm{p}<0,05$

The results of the Kruskal-Wallis H test, which are used to compare the scores obtained from the Parental Attitude Scale for Technology Use, the Mobile Addiction Scale and the Social Media Addiction Scale, according to daily internet usage time, are given in Table 6.

It was found that there was no statistically significant difference between sociopsychological development, interest and achievement of the course, internal and external quality of the course, learning and attendance subscale scores in the Parental Attitude Scale for Technology Use according to the daily internet usage time of the parents included in the study (p. > 0.05).

It was determined that the difference between the scores obtained from the emotional change, conflict, repetition, mobile internet tendency and mobile addiction subdimensions of the Mobile Addiction Scale according to the daily internet usage period of the parents was not statistically significant ( $p>0.05$ ). The difference between the scores obtained from the subscales of markedness, tolerance and divergence was found to be statistically significant $(p<0.05$ ). The scores obtained from the tolerance and divergence subscales of the parents whose daily internet usage time was 5 hours or more were found to be higher than the other parents. In addition, parents with a daily internet use of 5 hours or more scored higher on the markedness subscale than parents using the internet 3 hours or less per day.

It has been seen that there was no statistically significant difference between the scores obtained from the virtual tolerance and virtual communication sub-dimensions in the Social Media Addiction Scale according to the daily internet usage period of the parents $(\mathrm{p}>0.05)$. 
Table 7. Parental attitude scale for technology use, mobile addiction scale and social media addiction scale scores according to the type of operating system of parents $(n=200)$

\begin{tabular}{|c|c|c|c|c|c|c|c|c|}
\hline & OS & n & $\bar{x}$ & $\mathbf{s}$ & $\mathbf{M}$ & SO & $\mathbf{Z}$ & $\mathbf{p}$ \\
\hline \multirow{2}{*}{ Socio-Psychological Development } & IOS & 66 & 25,64 & 7,81 & 24,00 & 101,09 & \multirow{2}{*}{$-0,101$} & \multirow{2}{*}{0,919} \\
\hline & Android & 134 & 25,07 & 7,20 & 25,00 & 100,21 & & \\
\hline \multirow{2}{*}{ Interest and Success } & IOS & 66 & 22,98 & 5,91 & 23,00 & 88,67 & \multirow{2}{*}{$-2,035$} & \multirow{2}{*}{$\begin{array}{c}0,042 \\
*\end{array}$} \\
\hline & Android & 134 & 24,59 & 5,86 & 26,00 & 106,33 & & \\
\hline \multirow{2}{*}{$\begin{array}{l}\text { Internal and External Quality of the } \\
\text { Course }\end{array}$} & IOS & 66 & 13,64 & 3,66 & 14,00 & 91,67 & \multirow{2}{*}{$-1,523$} & \multirow{2}{*}{0,128} \\
\hline & Android & 134 & 14,34 & 3,94 & 15,50 & 104,85 & & \\
\hline \multirow{2}{*}{ Learning and Participation } & IOS & 66 & 9,94 & 2,53 & 10,00 & 94,95 & \multirow{2}{*}{$-0,961$} & \multirow{2}{*}{0,337} \\
\hline & Android & 134 & 10,36 & 2,50 & 11,00 & 103,23 & & \\
\hline \multirow{2}{*}{ Evidence } & IOS & 66 & 10,53 & 3,61 & 10,50 & 106,25 & \multirow{2}{*}{$-0,993$} & \multirow{2}{*}{0,321} \\
\hline & Android & 134 & 10,10 & 3,63 & 10,00 & 97,67 & & \\
\hline \multirow{2}{*}{ Tolerance } & IOS & 66 & 11,11 & 4,29 & 11,00 & 97,83 & \multirow{2}{*}{$-0,461$} & \multirow{2}{*}{0,645} \\
\hline & Android & 134 & 11,38 & 4,06 & 11,00 & 101,82 & & \\
\hline \multirow{2}{*}{ Estrangement } & IOS & 66 & 10,32 & 4,03 & 10,50 & 102,33 & \multirow{2}{*}{$-0,315$} & \multirow{2}{*}{0,752} \\
\hline & Android & 134 & 10,20 & 3,97 & 9,00 & 99,60 & & \\
\hline \multirow{2}{*}{ Emotional Change } & IOS & 66 & 10,29 & 3,46 & 11,00 & 94,22 & \multirow{2}{*}{$-1,082$} & \multirow{2}{*}{0,279} \\
\hline & Android & 134 & 10,99 & 3,51 & 11,00 & 103,59 & & \\
\hline \multirow{2}{*}{ Conflict } & IOS & 66 & 11,12 & 4,02 & 12,00 & 110,18 & \multirow{2}{*}{$-1,670$} & \multirow{2}{*}{0,095} \\
\hline & Android & 134 & 10,20 & 3,48 & 10,00 & 95,73 & & \\
\hline \multirow{2}{*}{ Repeat } & IOS & 66 & 10,47 & 3,82 & 11,00 & 101,77 & \multirow{2}{*}{$-0,219$} & \multirow{2}{*}{0,826} \\
\hline & Android & 134 & 10,59 & 4,14 & 10,00 & 99,87 & & \\
\hline Mohile Internet Trend & IOS & 66 & 12,52 & 3,43 & 12,50 & 96,52 & 5 & 403 \\
\hline 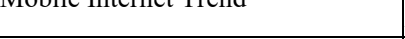 & Android & 134 & 12,91 & 3,57 & 13,00 & 102,46 & $-0,003$ & 0,493 \\
\hline Mohi & IOS & 66 & 14,50 & 4,78 & 14,00 & 99,04 & 0251 & 0.801 \\
\hline THODIE Aduction & Android & 134 & 14,31 & 4,17 & 14,00 & 101,22 & $-0,201$ & 0,001 \\
\hline Vintul Tolerance & IOS & 66 & 30,44 & 9,34 & 29,00 & 104,31 & 0654 & 0.513 \\
\hline virtual torerance & Android & 134 & 29,19 & 8,36 & 29,00 & 98,62 & $-0,054$ & 0,315 \\
\hline Virtual Communication & IOS & 66 & 24,91 & 8,72 & 24,00 & 107,27 & 1.163 & 0,245 \\
\hline र & Android & 134 & 23,24 & 7,55 & 22,00 & 97,16 & & \\
\hline
\end{tabular}

Table 7 shows the results of the Mann-Whitney U test conducted to compare the scores of the parents who participated in the study from the Parental Attitude Scale for the Use of Technology, the Mobile Addiction Scale and the Social Media Addiction Scale according to the type of mobile operating system.

It was found that the difference between the scores obtained from the sociopsychological development, internal and external quality of the course, learning and participation sub-dimensions of the Parental Attitude Scale for Technology Use was not statistically significant according to the type of mobile operating system $(p>0.05)$. It was seen that the difference between the scores obtained from the sub-dimension of interest and success in the course was statistically significant according to the type of mobile operating system used by the parents and it was seen that the parents using Android received higher scores in this sub-dimension.

It was found that the difference between the scores obtained from the subscales of the markedness, tolerance, divergence, emotional change, conflict, repetition, mobile 
internet tendency and mobile addiction were not found to be statistically significant according to the type of mobile operating system ( $\mathrm{p}>0.05)$.

It was found that there was no statistically significant difference between the scores obtained from the virtual tolerance and virtual communication subscales in the Social Media Addiction Scale according to the type of mobile operating system of the parents $(\mathrm{p}>0.05)$.

Table 8. Correlations between scores obtained by parents from Parental Attitude Scale for Technology Use, Mobile Addiction Scale and Social Media Addiction Scale $(n=200)$

\begin{tabular}{|c|c|c|c|c|c|}
\hline & & $\begin{array}{l}\text { Socio-Psychological } \\
\text { Development }\end{array}$ & $\begin{array}{l}\text { Interest and } \\
\text { Success }\end{array}$ & \begin{tabular}{|c|} 
Internal and \\
External Quality \\
of the Course
\end{tabular} & $\begin{array}{l}\text { Learning and } \\
\text { Participation }\end{array}$ \\
\hline \multirow{2}{*}{ Evidence } & $\mathrm{r}$ & 0,318 & $-0,068$ & $-0,058$ & 0,020 \\
\hline & $\mathrm{p}$ & $0,000 *$ & 0,339 & 0,416 & 0,775 \\
\hline \multirow{2}{*}{ Tolerance } & $\mathrm{r}$ & 0,165 & 0,049 & 0,108 & 0,108 \\
\hline & $\mathrm{p}$ & $0,020 *$ & 0,492 & 0,128 & 0,128 \\
\hline \multirow{2}{*}{ Estrangement } & $\mathrm{r}$ & 0,198 & $-0,126$ & $-0,058$ & 0,020 \\
\hline & $\mathrm{p}$ & $0,005^{*}$ & 0,076 & 0,413 & 0,784 \\
\hline \multirow{2}{*}{ Emotional Change } & $\mathrm{r}$ & 0,186 & $-0,006$ & 0,011 & 0,095 \\
\hline & $\mathrm{p}$ & $0,008^{*}$ & 0,931 & 0,875 & 0,180 \\
\hline \multirow{2}{*}{ Conflict } & $\mathrm{r}$ & 0,250 & $-0,002$ & 0,094 & 0,174 \\
\hline & $\mathrm{p}$ & $0,000^{*}$ & 0,976 & 0,186 & 0,014 \\
\hline \multirow{2}{*}{ Repeat } & $\mathrm{r}$ & 0,285 & $-0,058$ & $-0,003$ & 0,062 \\
\hline & $\mathrm{p}$ & $0,000^{*}$ & 0,415 & 0,963 & 0,383 \\
\hline \multirow{2}{*}{ Mobile Internet Trend } & $\mathrm{r}$ & 0,031 & 0,346 & 0,371 & 0,364 \\
\hline & $\mathrm{p}$ & 0,660 & $0,000 *$ & $0,000 *$ & $0,000^{*}$ \\
\hline \multirow{2}{*}{ Mobile Addiction } & $\mathrm{r}$ & 0,118 & $-0,017$ & $-0,018$ & 0,026 \\
\hline & $\mathrm{p}$ & 0,097 & 0,813 & 0,799 & 0,713 \\
\hline \multirow{2}{*}{ Virtual Tolerance } & $\mathrm{r}$ & 0,161 & $-0,074$ & $-0,013$ & 0,016 \\
\hline & $\mathrm{p}$ & $0,023^{*}$ & 0,298 & 0,852 & 0,818 \\
\hline \multirow{2}{*}{$\begin{array}{l}\text { Virtual Communica- } \\
\text { tion }\end{array}$} & $\mathrm{r}$ & 0,078 & 0,015 & 0,009 & 0,105 \\
\hline & $\mathrm{p}$ & 0,275 & 0,835 & 0,900 & 0,138 \\
\hline
\end{tabular}

${ }^{*} \mathrm{p}<0,05$

Table 8 shows the results of the Spearman correlation analysis conducted to determine the correlations between the scores of the Parental Attitude Scale for Technology Use, the Mobile Addiction Scale, and the Social Media Addiction Scale obtained by the parents covered by the study.

When the Table 10 was examined, it was observed that there were statistically significant and positive correlations between the scores obtained from the sociopsychological development subscale of the Parental Attitude Scale for Technology Use and the scores obtained from the subscale of markedness, tolerance, divergence, emotional change and repetition in the Mobile Dependency Scale (p. <0.05). As the scores obtained from the sociopsychological development sub-dimension of the parents increased, the scores obtained from the sub-dimension of markedness, tolerance, divergence, emotional change and repetition also increased. 
It was found out that the interest and success in the course, the internal and external quality of the course, learning and participation sub-dimensions of the Parental Attitude Scale for Technology Use and the mobile internet tendency of the Mobile Addiction Scale showed statistically significant correlations $(p<0,05)$. These correlations are positive, and as the scores of parents' interest and success, internal and external quality, learning and participation subscales increase, the scores obtained from the mobile internet tendency subscale also rise.

\section{Conclusion and Discussion}

In this study, which aims to determine the attitudes of students' parents towards mobile addiction and social media addiction levels and technology usage, important results have been obtained based on the findings and the most remarkable ones are given below.

Based on an examination of the technology use characteristics of the parents who participated in the study, it was concluded that $79 \%$ used mobile phone for making/receiving calls, $69.50 \%$ used it for social networks and $42.50 \%$ used it for education purposes whereas $78.0 \%$ had WhatsApp account and $76.0 \%$ used social media to communicate with their friends.

In the study, it was found that parents, $55.0 \%$ of whom were females and $45.0 \%$ of whom were males, had similar attitudes and opinions about technology use, social media and mobile addiction. However, it was concluded that male parents control mobile phone use more often than female parents, feel safer with, and are more addicted to mobile phone use.

Smart phones are widely used in several applications such as calling, texting, internet, navigation, gaming and social networks. With these applications, smart phones, which are among the indispensable elements of social life, have become a device that users want to check at any time. According to Lee, Chang, Lin and Cheng, who stressed that the desire to constantly check for messages or calls stems from habit, behaviors that force a person to these actions lead to mobile addiction [12].

Another finding is that parents have similar attitudes towards the use of technology in terms of sociopsychological development compared to age groups, and that only parents of 40 years and older have lower attitudes towards the use of technology by themselves and their children. Parallel to this result, Kuzu in his study titled "Internet and Family", found that as the duration and frequency of internet usage of parents increased, the rate of internet usage for communication purposes increased; it was also found that the usage of internet for communication purposes decreased in older ages [13].

Another finding is that compared to parents aged 35-39, parents aged 34 and under use mobile devices for less time, that their smart phones make them less comfortable, and that they have fewer problems with people around them. Another result is that parents who use internet for 5 hours and more a day check their phones more frequently and suffer from more frustration. In addition, it can be said that this group 
could not do without thinking about using their mobile phones more compared to the parents using internet for 3 hours or less per day.

The study conducted by Adikuzel et al. with the title "The effects of problematic internet usage of university students on family relationship" found that a considerable majority of families is adversely affected by problematic internet usage and that parents supported the internet usage of their children and that the usage duration increased gradually in the group which showed support [14].

In addition, there are statistically significant and positive correlations based on the research findings. Accordingly, as the attitudes of parents towards the use of technology increase, mobile addiction levels increase as well. When the changing world conditions, media and technology factors are considered, the responsibilities of the families become more serious and their burden becomes heavier as it is known that children take their families as a model while learning attitudes and values [15].

Another correlational result is that, as the attitudes of parents towards technology use increase, their mobile addiction and their access to the internet from mobile rises as well. Every user of all ages is intensely interested in internet technology. Society and technology are in constant interaction with each other. On the other hand, family is the cornerstone of society [16]. Parents need to be more careful with the Internet, mobile devices and social media instrument, given that children are always imitating and copying their parents.

In the light of these results, it is recommended that parents have information about technological developments, participate in trainings to be organized by educators on conscious use of Internet and social media monitoring, and that educators should organize courses and seminars for parents.

\section{Acknowledgement}

The work is performed according to the Russian Government Program of Competitive Growth of Kazan Federal University.

\section{References}

[1] TUIK - Turkiye İstatistik Kurumu (2018). Hanehalki Bilisim Teknolojileri Kullanim Arastirmasi. 30.07.2019 retrieved from http://www.tuik.gov.tr/PreHaberBultenleri. $\underline{\mathrm{do}} \mathrm{id}=27819$

[2] Ayaz, M., \& Karatas, K. (2016). Examining the Level of Internet Addiction of Adolescents in Terms of Various Variables. World Journal on Educational Technology: Current Issues, 8(3), 238-244. https://doi.org/10.18844/wjet.v8i3.780

[3] Fidan, H. (2016). Development and Validation of the Mobile Addiction Scale: The Components Model Approach. Addicta: The Turkish Journal on Addictions, 3, 433-469. https://doi.org/10.15805/addicta.2016.3.0118

[4] Sahin, C., \& Yağci, M. (2017). Social Media Addiction Scale - Adult Form: The Reliability and Validity Study. Ahi Evran University, Journal of Kirsehir Faculty of Education (KEFAD), 18(1), 523-538. 
[5] Eraslan, L., \& Kukuoğlu, A. (2019). Social relations in virtual world and social media aggression. World Journal on Educational Technology: Current Issues, 11(2), 01-11. https://doi.org/10.18844/wjet.v11i2.4145

[6] Odabasi, F. (2002) İnternet ve çocuk. (Edt: K. Peker). İstanbul: Kapital Medya Hizmetleri A.S.

Vryzas K. \& M. Tsitouridou (2002). Children and computers: Greek parents' expectation. Education Media International, 39 (3-4), 285-297.https://doi.org/10.1080/095239 $\underline{80210166053}$

[7] Karasar, N. (2002). Bilimsel Arastirma Yontemleri. Ankara: Nobel Yayinlari.

[8] Fraenkel, J. R., Wallen, N. E., \& Hyun, H. H. (2012). How to design and evaluate research in education (8th edition). New York: McGraw Hill

[9] Balci, A. (2007). Sosyal Bilimlerde Arastirma. Ankara: PegemA Yayincilik.

[10] Kenar, İ. (2012). Development of parents' attitude scale regarding technology and use of technology in classes and tablet PC application. Journal of Educational Sciences Research, 2 (2), 123-139. http://ebadjesr.com/

[11] Lee, Y. K., Chang, C. T., Lin, Y., \& Cheng, Z. H. (2014). The dark side of smartphone usage: Psychological traits, compulsive behavior and technostress. Computers in Human Behavior, 31, 373-383. https://doi.org/10.1016/j.chb.2013.10.047

[12] Kuzu, A. (2011). İnternet ve aile. Aile ve Toplum Eğitim-Kültür ve Araştırma Dergisi, 7(27), 09-32.

[13] Adikuzel, F., Bekleyiciler, S., Demirel, A., Ergurum, O., Eroglu, A., Kuren, H., \& San, F. (2018). The effects of problematic internet usage of university students on family relationship: example of kto karatay university faculty of social and humanity science. Undergraduate Department of Social Work. KTO Karatay University.

[14] Hokelekli, H., \& Gunduz, T. (2007). Üstun yetenekli çocuklarin değer yonelimleri ve eğitimleri. Değerler ve Eğitimi içinde (371-396). İstanbul: Dem Yayinlari.

[15] Kirik, A. M. (2014). Place of Internet in Family and Child Relationship: Qualitative Research. Journal of Research in Education and Teaching.

[16] Bukhori, B., Said, H., Wijaya, T., \& Nor, F. M. (2019). The Effect of Smartphone Addiction, Achievement Motivation, and Textbook Reading Intensity on Students' Academic Achievement. International Journal of Interactive Mobile Technologies, 13(9). https://doi.org/10.3991/ijim.v13i09.9566

[17] Nawaila, M. B., Kanbul, S., \& Uzunboylu, H. (2018). Toward Making Social Media Effective in our Classrooms: A 9-Point Method. International Journal of Interactive Mobile Technologies, 12(4). https://doi.org/10.3991/ijim.v12i4.9201

[18] Hamutoglu, N, Gezgin, D., Sezen-Gultekin, G., \& Gemikonakli, O. (2018). Relationship between nomophobia and fear of missing out among Turkish university students. Cypriot Journal of Educational Sciences, 13(4), 549-561.https://doi.org/10.18844/cjes. v13i4.3464

[19] Kurt, A., Dogan, E., Erdogmus, Y., \& Emiroglu, B. (2018). Examining computer gaming addiction in terms of different variables. World Journal on Educational Technology: Current Issues, 10(1). https://doi.org/10.18844/wjet.v10i1.3328

\section{$7 \quad$ Authors}

Sezer Kanbul is with the Department of Computer Education \& Instructional Technology, Near East University, P.O. Box: 99138, Nicosia, North Cyprus. E-mail: sezer.kanbul@neu.edu.tr. 
Taymuraz E. Kallagov is $\mathrm{PhD}$ in Law, Associate Professor, Head of the Department of Constitutional Law at Gorsky State Agrarian University (RSO-Alaniya, 362040, Vladikavkaz, Russia). He is a well-known in Russia as a scientist in the sphere of constitutional law. His research interests are also connected with law education, educational environment, and scientific methodology. E-mail: tkallagov@bk.ru

Vladimir E. Rubanik is a Doctor in Law, Professor of the Department of Legal Regulation of Economic Activity at Financial University under the Government of the Russian Federation (49 Leningrad sky prospects, 125993, Moscow, Russia). He is a member of editorial board of Russian scientific journal "Modern Lawyer". His research interests are connected with history of Russian law and history of education. Email: vladimir-rubanik@yandex.ru

EImira R. Khairullina is a Doctor of Education, Professor, Dean of the Faculty of Design and Software Engineering at Kazan National Research Technological University (68 Karl Marks Street, 420015, Kazan, Russia). Her main scientific and professional interests are connected with professional standards and programs, engineering education. She actively studies the problems of adult education, teacher education and educational environment possibilities. She is a member of the Federal Educational Methodical Association of Russian universities on an integrated group of areas of light industry technology, and also a member of dissertation council for the award of scientific degrees. She has more than 100 published articles in Russian and International journals. E-mail: elm.khair73@gmail.com

Laysan A. Ribakova is a Deputy Director for Educational and Social Work at the Institute of Psychology and Education of Kazan (Volga region) Federal University (18 Kremlyovskaya Street, 420000, Kazan, Russia). Her research interests are related to the methodology of students' education and upbringing, their self-education, self-assessment and self-management. She is an organizer of more than 10 Russian and International conferences and forums on the problems of teacher education. Kazan, Russia. E-mail:lilor1@,rambler.ru

Article submitted 2019-09-25. Resubmitted 2019-11-02. Final acceptance 2019-11-03. Final version published as submitted by the authors. 